\title{
The Group-lending Model and Social Closure: Microcredit, Exclusion, and Health in Bangladesh
}

\author{
Anna T. Schurmann' and Heidi Bart Johnston² \\ 'University of North Carolina, Chapel Hill, USA and ${ }^{2}$ ICDDR,B, GPO Box I28, Dhaka I000, Bangladesh
}

\begin{abstract}
According to social exclusion theory, health risks are positively associated with involuntary social, economic, political and cultural exclusion from society. In this paper, a social exclusion framework has been used, and available literature on microcredit in Bangladesh has been reviewed to explore the available evidence on associations among microcredit, exclusion, and health outcomes. The paper addresses the question of whether participation in group-lending reduces health inequities through promoting social inclusion. The group-lending model of microcredit is a development intervention in which small-scale credit for income-generation activities is provided to groups of individuals who do not have material collateral. The paper outlines four pathways through which microcredit can affect health status: financing care in the event of health emergencies; financing health inputs such as improved nutrition; as a platform for health education; and by increasing social capital through group meetings and mutual support. For many participants, the group-lending model of microcredit can mitigate exclusionary processes and lead to improvements in health for some; for others, it can worsen exclusionary processes which contribute to health disadvantage.
\end{abstract}

Key words: Exclusion; Economic assistance; Health status; Group-lending model; Health equity; Microcredit; Social exclusion; Bangladesh

\section{INTRODUCTION}

According to social exclusion theory, health risks are positively associated with involuntary social, economic, political and cultural exclusion from society. Microcredit is a development intervention designed to reduce poverty through access to credit. While not explicitly designed to impact health as a poverty reduction strategy, microcredit interventions have the potential to empower borrowers, and through several different pathways, improve health. Microcredit programmes have been adapted to different contexts all over the world, in rich and poor countries, with an estimated 92 million clients in the developing world (1). The year 2005 was named the 'Year of Microcredit' by the UN's Economic and Social Council. In 2006, Mohammed Yunus won the Nobel Prize for Peace for his work with the Grameen Bank.

Correspondence and reprint requests should be addressed to:

Anna T. Schurmann

Carolina Population Center

University of North Carolina

CB 8120

Chapel Hill, NC 27516, USA

Email: annaschurmann@unc.edu
We use a social exclusion framework and draw on the available literature on microcredit in Bangladesh to explore associations between participation in microcredit programmes, social exclusion, and health status. We begin with a description of the multiple exclusionary factors that microcredit seeks to combat, specifically poverty, the traditional norms that govern women's conduct in public, and urban-rural inequalities in wealth and development. We then explain the group-lending model of microcredit, and drawing upon the available evidence, suggest four pathways in which microcredit can impact health. Ultimately, we argue that while group-based microcredit programmes have the potential to help borrowers raise themselves out of poverty, these programmes can also replicate exclusionary processes in society and further health inequity.

\section{MICROCREDIT}

The microcredit movement in Bangladesh is an important story in contemporary development discourse, both because of its origins within the country and because of its reach in the population. The agricultural cycle in Bangladesh has always been closely tied to the provision of credit. Traditionally, 
small cultivators relied on money-lenders for agricultural inputs or consumption requirements until harvest (2). Provision of formal microcredit, with goals of sustainable poverty reduction, began in 1959 by Akter Hameed Khan in what was called the 'Comilla Model' (after a town by the same name) by the Pakistan Rural Development Board (later named the Bangladesh Rural Development Board). However, this experiment achieved only isolated success due to elite capture and a lack of community buy-in. Over time, different strategies of microcredit have been explored, and different finance products developed (all under the broader term of 'microfinance'). The movement has expanded in the last decades; there are now over 1,500 microfinance institutions in Bangladesh (1).

The two primary providers of microcredit in Bangladesh are the Grameen Bank and Building Resources Across Communities (now BRAC, formerly Bangladesh Rural Advancement Committee), both of which started their operations in the late 1970s. These organizations work to tie social development goals with provision of credit. While BRAC uses various interventions to assist the poor and has a strong emphasis on consciousness-raising, Grameen Bank's main focus is microcredit. Grameen Bank has over 2,247 branches, covering 72,096 villages, with a total of four million borrowers, and BRAC has an estimated 3.6 million borrowers through its 50,000 village organizations $(1,3)$. There are a number of different models of microcredit delivery; however, both BRAC and Grameen Bank use the group-lending model-the model discussed in this paper.

The main attribute of the group-lending model of microcredit is the use of social rather than material collateral. Loans are made to small groups or cooperatives, and peer pressure is used for ensuring that repayments are made. In Bangladesh, women are the primary beneficiaries of microcredit programmes-not necessarily out of a feminist impulse but because there is evidence that women are more sensitive to peer pressure and so are more reliable debtors. In the absence of material collateral and credit-rating systems, the group-lending model makes use of information 'impacted' in the village about who is a reliable borrower, and villagers reveal such information by using their judgement to select fellow debtors for the small groups. In this way, the group-based lending model both uses and builds upon the social capital of its borrowers. This makes group-based lending efficient and effective, with low transaction costs for the provider $(4,5)$.
Any extra income earned through participation in a microcredit scheme can be spent on what microcredit clients (or their households) see as their highest priority; so, the intervention can be viewed as less paternalistic and more enabling than other development interventions (6).

While microcredit is an indigenous solution to local poverty in Bangladesh, many international actors were instrumental in its growth and expansion, including Chicago's South Shore Bank, the Ford Foundation, and the World Bank. The many different donors have brought different priorities and ideologies, reporting procedures, and indicators that have shaped the practice of microcredit (7).

\section{EXCLUSION IN BANGLADESH}

In this analysis, we explore the available evidence on associations between microcredit and exclusion and health status. Processes that create inequities have traditionally been understood in terms of market exploitation, or the extraction of surplus value. However, market exploitation alone does not account for many inequity-producing processes. The social processes that 'shut out' certain categories of people from the benefits of participation could better be described as exclusion or social exclusion (8). This analysis explores the factors that have traditionally excluded certain groups from financial markets in Bangladesh. The principal factors identified are poverty (economic exclusion), regional disparities (spatial exclusion), and the low-status of women (cultural exclusion). This analysis presents each of these factors in isolation, but in reality, these factors compound each other as components of deprivation and exclusion and have causal and dynamic connections (9). The figure is a conceptual model depicting the relationship of social exclusion to poor health outcomes in Bangladesh as described in this paper. The model depicts that cultural, spatial and economic exclusions are encompassed under the umbrella of 'social exclusion'.

\section{Economic exclusion}

The poverty levels in Bangladesh have always been high. Post-independence levels of income poverty in Bangladesh in the mid-1970s were estimated at $70-80 \%$. With rates of economic growth over 5\% annually, poverty rates in Bangladesh have been declining by about $1 \%$ a year since the 1990 s (10). According to the 2005 estimates, the poverty level is $40 \%$ in urban and $44 \%$ in rural Bangladesh. This overall decline in poverty masks the concurrent increase in income and asset inequality, with rural 


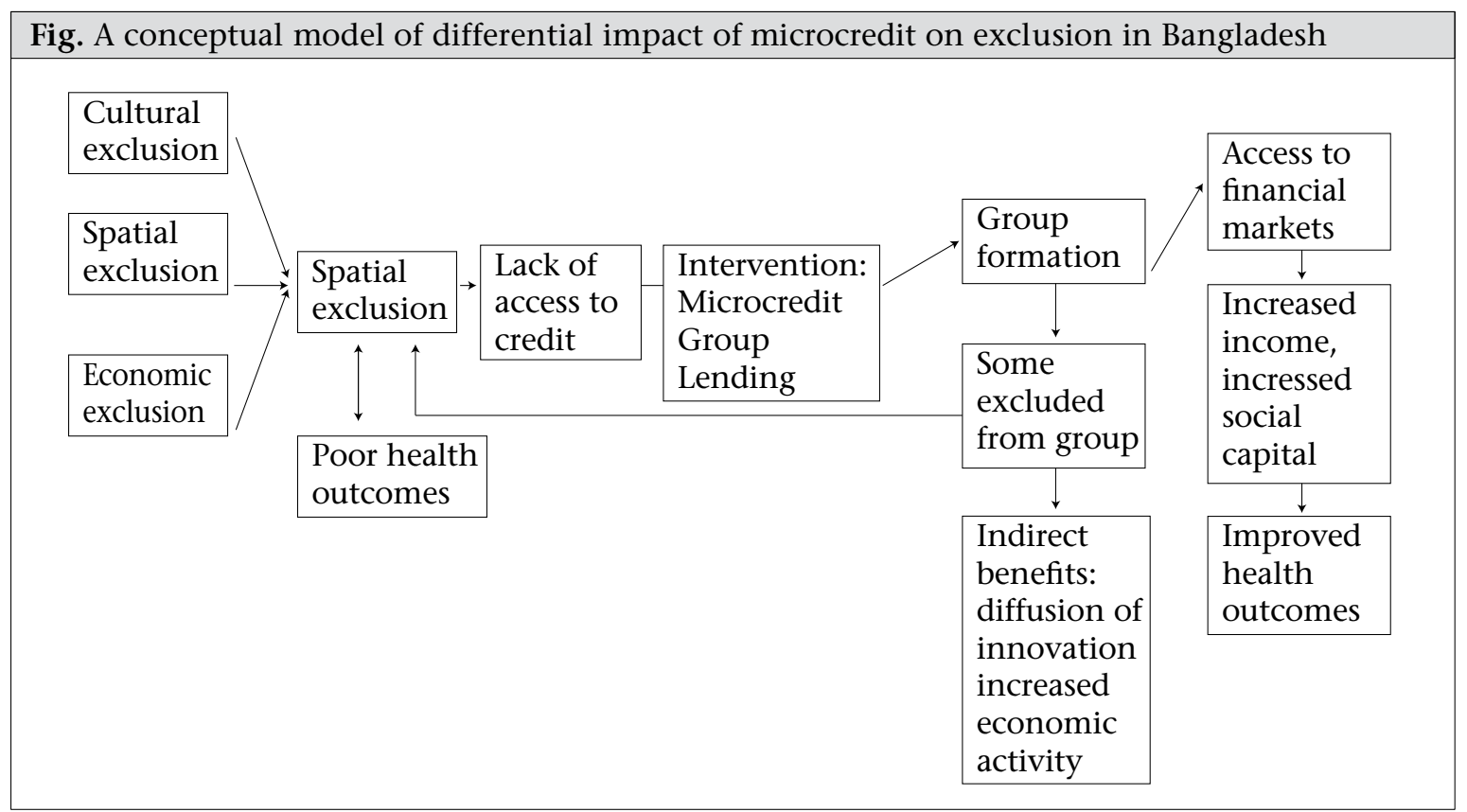

areas at a particular disadvantage. The Gini coefficient for consumption expenditure for rural areas rose from 0.28 in 1991-1992 to 0.31 by 2000 . In urban areas, it climbed from 0.36 to 0.41 (9).

The poor are not a homogenous group. While estimates vary, about $10 \%$ of the poor can be classified as 'ultra-poor' as measured by indicators, such as low consumption, low height-for-age, no formal education, high rates of infant mortality, and lack of access to essential services (10). This segment of the population is particularly vulnerable to factors that will increase deprivation: loss of assets (due to flooding for example), health emergencies, unstable livelihoods, and poor sanitation. Such chronic insecurity often leads to livelihood strategies that prevent mobility out of poverty, such as irregular day labour, begging, or sex work (11).

\section{Spatial exclusion}

The rural poor are not only excluded from economic growth through lack of financial resources and assets but also through their distance from opportunities in the urban economy. There is also spatial disadvantage within rural areas associated with low 'geographic capital': uneven distribution of services and infrastructure, low agricultural or resource potential, and weak economic and transport linkages $(9,11,12)$. Data on rural poverty levels since 2000 vary from $61 \%$ in Rajshahi to $40 \%$ in Barisal (11). However, the importance of place to variation in health is not just a matter of geography but also dynamic social and political relationships
$(11,12)$. For example, particular electorates may be favoured as vote-banks during the election cycle.

\section{Cultural exclusion—purdah}

Purdah is a social and Islamic religious tradition that prohibits women from mixing with men who are not blood relatives, after the onset of menarche. Norms vary but generally purdah denies women access to productive capital and markets (13); women in purdah are not allowed to work, touch money, or go to the market. While restrictions are, to an extent, negotiable (2), adhering to purdah grants status and privilege, and conversely, violating purdah means loss of status and can be a sign of downward economic mobility. Typically, purdah confines women's work to the domestic sphere where it is under-valued and not remunerated. For example, if women work outside the household during the peak agricultural season, they would normally be paid in kind, not in cash to avoid violation of purdah (14). Restriction to the domestic sphere limits social networks, participation in civil society, and a voice in policy dialogue.

\section{TARGETING THE EXCLUDED}

In the previous section, barriers to inclusion in financial markets are described. Microcredit interventions need to overcome these barriers to reach those in need to be able to claim success. The clientele for microcredit are generally subsistence level, economically active, poor rural women. However, the programmatic targeting practices vary according to the priorities of the lender. If more reliable 
debtors are targeted, the transformative potential of microcredit to help the poorest is lower, but the profitability and sustainability are higher. This section describes how microcredit fares in targeting those most in need as it balances the contrary imperatives of reach and sustainability.

\section{Targeting the ultra-poor}

Borrowers with assets and skills are able to make better use of credit and provide lenders with higher returns (15). In his study of characteristics of poverty dynamics in Bangladesh, Sen found that rural ascendent households had greater access to credit than chronically poor and descendent households, suggesting that access to financial capital was an important element in the climb out of poverty (11).

At the same time, the ultra-poor and descendent individuals and households typically face barriers to joining traditional microcredit programmes, such as lacking the initial endowment (material and non-material collateral), high opportunity costs, and limited capacity for labour substitution. Even when included in microcredit programmes, some groups, such as landless casual labourers, are less able to benefit because they do not have a regular income that would enable them to commit to repayments, including interest. A loan for such borrowers only means increased insecurity and risk (5). It is generally acknowledged that traditional group-lending microcredit programmes are not appropriate for the ultra-poor, see for example, the World Bank's Consultative Group's 'Key Principles' (16). By benefiting only the marginally poor, microcredit can further isolate the ultra-poor by increasing inequality.

In response to this, BRAC has developed a programme specifically to target the ultra-poor with the aim of enabling them to gain the resources necessary to gainfully participate in traditional microcredit programmes (17). When the ultra-poor are specifically targeted as clients, conditionalities are often more generous; for example, the loans may be small with no interest and no repayment timeframe (17).

\section{Targetting rural areas}

Microcredit programmes in Bangladesh have generally concentrated in rural areas and have achieved many successes. However, as mentioned earlier, Bangladesh has many rural areas that are vulnerable to flooding, have poor transport infrastructure, and are otherwise economically less viable. As programmatic sustainability is more difficult in such areas $(18,42)$, these are less attractive to microcredit programme implementers and are avoided. Residents of areas with low geographic capital still face barriers to accessing financial markets (18).

\section{Targeting women}

Targeting is also gendered since microcredit generally focuses on women as efficient agents for the welfare of the household and as low-risk borrowers. Women present less credit risks, with default rates of only $3 \%$ compared to $10 \%$ for men (19). As debtors, women are seen as more passive, submissive, and vulnerable, making them more liable to make repayments (18). Repayments and debt collection can put significant pressure on women because they do not necessarily directly control household resources (20). While the burden of repayments are borne by women, the loan itself and income from microenterprise are often passed onto husbands or sons (21). This means that the ability of microcredit to empower women cannot be measured through client lists or timely repayments. Kabeer, instead, suggests that the measurement of empowerment needs to be within the local context, taking into account the perceptions of the beneficiaries themselves (2). Of course, impact is unlikely to be even. Women are not a homogenous group, and their contexts differ. Different individuals in different situations are likely to take advantage of different opportunities in different ways, or not at all. As previously mentioned, those with assets and skills, those closer to towns with access to opportunities for commerce, and those with more support from their families are more likely to benefit from microcredit.

To participate in microcredit activities, women must negotiate purdah barriers and balance microcredit obligations with childcare, subsistence, and other domestic duties. Compared to entry into the formal labour sector (e.g. a job in a garment factory), microcredit is easier to accommodate with purdah restrictions and household and childcare commitments. Thus, microcredit can serve as an intervention to assist women and households in the transition from the declining agricultural sector into the formal sector.

\section{SOCIAL CAPITAL AND SOCIAL EXCLUSION}

Through regular group meetings, group-based lending models of microfinance programming can develop new social capital and networks for participants. The mutual support and solidarity of 
the group provides an atmosphere of collective selfinterest (4). As a result, those who traditionally have been marginalized may become more organized and gain a stronger voice, which can lead to higher levels of political awareness and participation (2). However, the transformative potential of enhanced social capital should not be overstated. Success of microfinance depends on peer pressure (social collateral) as a substitute for material collateral and insurance against late or non-payment. Peer pressure, in turn, depends on membership to the group, or social inclusion. Peer pressure is used both as a disciplinary and support mechanism within microcredit, and the balance between these two functions is a fine one. Goetz finds that the emphasis on peer pressure as a disciplinary force in BRAC microcredit groups has undermined trust and support and increases the likelihood that the poor and most vulnerable will be excluded (20). People who lapse on their payments are punished with reclamation of their assets but, more importantly, non-payment results in social sanction.

In an ethnographic study, Todd provides a further account of social relationships within microcredit programmes (22). Todd found that group solidarity is tenuous and does not usurp or disrupt traditional kin or patron-client networks, where stronger loyalties tend to reside. Indeed, such relationships are key to women's survival and success in microcredit programmes. Todd points out "these (kin and patron-client) relationships are vital to women because they are dependent, but they can also be used to negotiate their independence." Todd also reports that successful members of credit groups are highly intolerant of less successful group members, even when the lack of success was clearly not their fault. Failure to meet group norms can lead to social exclusion (22).

While microcredit counters the exclusion of the poor from access to formal lending, it does not cater to those who are subjected to high levels of exclusion. The logic of relying on social collateral rather than material collateral inherently means that there will always be some who are excluded (for example, widows, migrant labourers, single mothers, people with stigmatizing illnesses). Inequalities in social collateral lead to unequal access to microcredit and its potential benefits $(8,21)$. Unfortunately, women are not judged on their own merit alone, but often risk being denied participation in lending groups if their husbands drink or gamble, or otherwise pose a credit risk $(18,21)$. In these instances, microcredit reinforces existing social processes of exclusion (8).

\section{MICROCREDIT, MEASUREMENT, AND HEALTH STATUS}

Participation in microcredit programmes is associated with positive health behaviours and outcomes in numerous studies (Table) (for a meta-analysis, see also Morduch J, 2001). However, these data need to be viewed with some caution. The socially-embedded nature of microcredit group makes causality difficult to prove $(7,23)$. Membership in credit groups depends and builds on social capital, which may itself be correlated with education and healthcare-seeking behaviours. Women who join microcredit programmes likely have access to more social capital from the outset. This point is demonstrated by Steele et al. (1998), who used a quasi-experimental panel design to identify the characteristics of women who chose to join microcredit programmes $(21,24)$. They found that the women who joined were relatively educated and socially independent compared to those who did not join. However, after controlling for this selection bias, they still identified a positive impact with regard to children's education, age at marriage, and use of modern contraception. On the other hand, Mahmud suggests that selection bias goes the other way, with the least empowered women being the most likely clients of microcredit (24). Either way, selection bias provides a hurdle to proving causality, even with multivariate analysis. One must consider that microcredit may only help those who are already economically ascendant.

Similarly, the pathways from microcredit to health are not always explicit. This analysis draws on the literature to suggest four broad pathways in which microcredit could have a positive impact. For the purpose of this analysis, these are presented as unique pathways. In reality, the pathways cross and intermingle, their individual impact difficult to tease out.

First, microcredit serves as a medium to communicate health messages. When borrowers participate in regular repayment meetings, they may be (depending on the programme) provided with health education or service provision, increasing their knowledge of and access to formal healthcare. The regular meetings associated with the group-based lending models of microfinance programming provide a forum for education and training. BRAC programmes, more often than Grameen Bank, capitalize on this opportunity to provide regular contact with a health educator. Grameen Kalyan (the healthcare arm of Grameen Bank) now provides primary healthcare services in operational 
areas and ancillary health services, such as health insurance (25). Providing learning opportunities alongside credit is not just altruism on the part of the lender; increasing general capacity of the poor cultivates more capable clients (4). Ill-health is the most common reason for loan defaulting, which benefits neither the lender nor the borrower. Microcredit participants are likely to be influential within their social network due to their upward mobility (typical 'innovators'), and new health knowledge and behaviours are likely to diffuse quickly from group participants to the rest of the community (26).

Second, microcredit can improve the general quality of life of borrowers by increasing disposable income, reducing vulnerability through diversifying income sources, strengthening financial shock-coping mechanisms (insurance, savings), and building assets. A large literature demonstrates the bi-directional relationships between health and economic status (27). Nanda documented that income from microcredit increased women's perceived and actual contribution to the household. This resulted in a positive impact on their decisions to seek quality healthcare (28). Evidence has also shown that women are more likely than men to spend earned income to benefit the entire household on items, such as food, education, and asset building (29). Pitt et al. found that access of women to credit from group-based credit programmes had a large and statistically significant effect on the health of both boy and girl children whereas access of men to credit had no effect (30). There is also evidence that increased income for women improves child and maternal health through increased school attendance and increased contraceptive use (Table).

Third, availability of credit can assist the poor with financing health emergencies, such as ill-health of the main breadwinner. The main difference from the point above is the immediacy of a need to finance a curative health emergency as opposed to a slower process of building a healthier and more secure household. Health emergencies are strongly related to impoverishment in Bangladesh. Costs of treatment and medicines can easily consume an entire household budget, especially if the household members do not have a regular source of income. Sale of productive assets to pay for healthcare often leads households into downward trajectories, pushing families into the category of 'ultra-poor' $(8,31)$.

The final pathway is building social capital through group meetings and mutual support, which has been demonstrated to improve health in and of itself (32). The social interaction in the group meetings has been found to play an important role in the diffusion of innovative behaviours such as contraceptive-use (23). However, as Portes has pointed out, social capital can equally function in both an exclusive or inclusive way-with positive welfare effects from some and negative for others $(33,34)$. This paper suggests that this is the likely outcome of group-based lending interventions; with economic and social benefits for those included within the lending group, and a denial of benefits to those purposefully excluded from the group. In this way, the mechanisms of group closure are re-aligned according to group credit membership (23). However, the impact of exclusion from microcredit on health requires further study as most studies compare microcredit participants to a control group, not to those who were excluded from joining a microcredit group.

\section{DISCUSSION}

A substantial body of literature about microcredit in Bangladesh shows that participation in a microcredit programme is associated with improved health behaviours and outcomes. Using social exclusion theory and drawing upon the literature around social capital, this analysis unpacks the relationships between microcredit and health, suggesting that microcredit has the potential to improve the health of participants. However, typical of a market-based solution, it is not equitable. By excluding individuals through the social processes of group formation, individuals and households are also excluded from the compounded benefits of microcredit, including the social support it engenders (Fig.). In this way, it replaces the economic exclusions of the market with exclusion through social processes. For this reason, it cannot be relied upon to ensure health equity.

Social exclusion analysis helps reveal the exclusions perpetuated by microcredit. While it can be an effective and transformative intervention, it should not be implemented at the expense of other interventions, such as infrastructure projects, service provision, or targeted subsidies. It cannot replace a vibrant public sector in providing capabilities to the poor for development. However, this article does not suggest a rejection of marketbased solutions to poverty and health inequity. This article argues that complementary interventions are needed to buffer exclusionary impacts of microcredit. 


\begin{tabular}{|c|c|c|c|}
\hline Topical area & Association with health & Study design & Author and year \\
\hline Access to care & $\begin{array}{l}\text { Use of private doctor } \\
\text { and pharmacy: } 15.4 \% \text { in } \\
\text { intervention area and } 11 \% \\
\text { in control area; knowledge of } \\
\text { government gynaecological } \\
\text { doctor: } 60 \% \text { in intervention } \\
\text { area and } 8 \% \text { in control area }\end{array}$ & $\begin{array}{l}3 \text { household surveys: } \\
1992(\mathrm{n}=656) \text {, } \\
1997(\mathrm{n}=2,105 \text {-intervention; } \\
\mathrm{n}=1,721-\text { control) and } 1998 \\
\text { ( } \mathrm{n}=1,068 \text {-intervention; } \\
\mathrm{n}=700 \text {-control group) }\end{array}$ & $\begin{array}{l}\text { Amin et al., } 2001 \\
(35)\end{array}$ \\
\hline Access to care & $\begin{array}{l}\text { Women's involvement in } \\
\text { credit programmes increased } \\
\text { the likelihood that curative } \\
\text { care was accessed; involvement } \\
\text { in IGAs decreased likelihood } \\
\text { Household wealth decreased } \\
\text { likelihood of child } \\
\text { experiencing illness episode } \\
\text { Travel time negatively } \\
\text { associated with use of care } \\
\text { provider }\end{array}$ & $\begin{array}{l}1997 \text { cross-sectional household } \\
\text { survey }(n=2,304) \text { in two } \\
\text { regions }\end{array}$ & $\begin{array}{l}\text { Levin et al., } 2001 \\
(36)\end{array}$ \\
\hline Access to care & $\begin{array}{l}\text { Participation in microcredit } \\
\text { programme has a positive } \\
\text { significant effect on level of } \\
\text { health knowledge }\end{array}$ & $\begin{array}{l}\text { Cross-sectional household } \\
\text { survey }(\mathrm{n}=1,798) \text { in } 87 \\
\text { randomly-sampled districts } \\
\text { Controls for endogeneity } \\
\text { with a weighted 2-stage } \\
\text { instrumental variable-land } \\
\text { ownership }\end{array}$ & Nanda, 1998 (28) \\
\hline $\begin{array}{l}\text { Acute } \\
\text { respiratory } \\
\text { infections } \\
\text { (health } \\
\text { knowledge) }\end{array}$ & $\begin{array}{l}34.4 \% \text { of mothers in the } \\
\text { intervention site were aware } \\
\text { of all symptoms of ARI, and } \\
30.7 \% \text { knew } 2+\text { preventative } \\
\text { measures; } 15.8 \% \text { of women } \\
\text { were aware of all symptoms in } \\
\text { control group and } 15.8 \% \text { knew } \\
2+\text { preventative measures }\end{array}$ & $\begin{array}{l}\text { Cross-sectional survey } \\
(\mathrm{n}=2,814) \text { in } 200 \text { randomly- } \\
\text { selected villages }\end{array}$ & Hadi, 2002 (37) \\
\hline Child survival & $\begin{array}{l}52 \% \text { reduction in baseline } \\
\text { level of infant mortality } \\
\text { for intervention mothers } \\
\text { compared to a } 31 \% \text { reduction } \\
\text { in child mortality for control } \\
\text { group. There was also a } \\
\text { reduction in child mortality for } \\
\text { children aged } 1-4 \text { year(s), but } \\
\text { with little difference between } \\
\text { the intervention and the } \\
\text { control group }\end{array}$ & $\begin{array}{l}\text { Quasi-experimental. DSS } \\
\text { survey data, membership } \\
\text { records of BRAC } \\
(\mathrm{n}=13,549)\end{array}$ & $\begin{array}{l}\text { Bhuiya et al., } \\
2002 \text { (38) }\end{array}$ \\
\hline $\begin{array}{l}\text { Domestic } \\
\text { violence }\end{array}$ & $\begin{array}{l}\text { Credit programmes reduce } \\
\text { vulnerability of women to } \\
\text { domestic violence }\end{array}$ & $\begin{array}{l}\text { Ethnographic study } \\
\text { (participant-observation, } \\
\text { in-depth interviews) }\end{array}$ & $\begin{array}{l}\text { Schuler et al., } \\
1996(39)\end{array}$ \\
\hline
\end{tabular}




\begin{tabular}{|c|c|c|c|}
\hline \multicolumn{4}{|c|}{ Table-Contd. } \\
\hline $\begin{array}{l}\text { Domestic } \\
\text { violence }\end{array}$ & $\begin{array}{l}\text { Membership to microcredit } \\
\text { programmes can both prevent } \\
\text { and exacerbate domestic } \\
\text { violence }\end{array}$ & $\begin{array}{l}\text { Ethnographic study } \\
\text { (participant-observation, in- } \\
\text { depth interviews) }\end{array}$ & $\begin{array}{l}\text { Schuler et al., } \\
1998(13)\end{array}$ \\
\hline $\begin{array}{l}\text { Family } \\
\text { planning }\end{array}$ & $\begin{array}{l}59 \% \text { of Grameen Bank } \\
\text { members using contraceptive } \\
\text { as opposed to } 43 \% \text { in matched } \\
\text { control group }\end{array}$ & $\begin{array}{l}\text { Quasi-experimental panel } \\
\text { design }\end{array}$ & $\begin{array}{l}\text { Schuler et al., } \\
1994(40)\end{array}$ \\
\hline $\begin{array}{l}\text { Family } \\
\text { planning }\end{array}$ & $\begin{array}{l}\text { Participation in rural income- } \\
\text { generating projects increased } \\
\text { contraceptive-use and a } \\
\text { decreased desire for additional } \\
\text { children }\end{array}$ & $\begin{array}{l}\text { Random cluster sample cross- } \\
\text { sectional household survey } \\
\text { Intervention group: } n=2,285 \text {; } \\
\text { control group: } n=1,168\end{array}$ & $\begin{array}{l}\text { Amin et al., } 1994 \\
\text { (14) }\end{array}$ \\
\hline $\begin{array}{l}\text { Family } \\
\text { planning }\end{array}$ & $\begin{array}{l}\text { Association between } \\
\text { programme membership } \\
\text { and contraceptive-use, desire } \\
\text { for smaller families. Also an } \\
\text { association between these } \\
\text { factors and living in the } \\
\text { programme area }\end{array}$ & $\begin{array}{l}1995 \text { cross-sectional household } \\
\text { survey in } 5 \text { regions }\end{array}$ & $\begin{array}{l}\text { Amin et al., } 1996 \\
\text { (41) }\end{array}$ \\
\hline $\begin{array}{l}\text { Family } \\
\text { planning }\end{array}$ & $\begin{array}{l}36.2 \% \text { contraceptive-use in } \\
\text { intervention area compared to } \\
13.7 \% \text { in control area }\end{array}$ & $\begin{array}{l}\text { Pre- and post-test control } \\
\text { panel survey } \\
1993(n=6,456) \text { and } 1995 \\
(n=5,696) \\
\text { cluster sampling }\end{array}$ & $\begin{array}{l}\text { Steele et al. } 2001 \\
(42)\end{array}$ \\
\hline $\begin{array}{l}\text { Maternal } \\
\text { health }\end{array}$ & $\begin{array}{l}\text { Membership in Grameen } \\
\text { Bank or BRAC per se has } \\
\text { no significant effect on any } \\
\text { contraceptive and reproductive } \\
\text { behaviour indicators. However, } \\
\text { the longer a woman is a } \\
\text { member of an NGO credit } \\
\text { programme, the more likely } \\
\text { she is to use a temporary } \\
\text { or permanent method of } \\
\text { contraception, even after } \\
\text { controlling other variables }\end{array}$ & $\begin{array}{l}\text { Randomized control design, } \\
\text { survey }\end{array}$ & $\begin{array}{l}\text { Meekers et al., } \\
1992 \text { (43) }\end{array}$ \\
\hline Nutrition & $\begin{array}{l}10 \% \text { increase in credit } \\
\text { increases arm circumference of } \\
\text { daughters by } 6.3 \% \text {. There is a } \\
\text { smaller effect on sons }\end{array}$ & $\begin{array}{l}\text { Multi-purpose quasi- } \\
\text { experimental household } \\
\text { survey, cluster sampled, } \\
\text { conducted in } 87 \text { villages of } 29 \\
\text { upazilas, } \\
\text { 1,538 eligible samples }\end{array}$ & $\begin{array}{l}\text { Pitt et al., } 2003 \\
\text { (30) }\end{array}$ \\
\hline $\begin{array}{l}\text { Health } \\
\text { knowledge }\end{array}$ & $\begin{array}{l}\text { Microcredit membership and } \\
\text { participation in health forum } \\
\text { are associated with a higher } \\
\text { knowledge of prenatal and } \\
\text { postnatal care } \\
\text { Causal relationship cannot be } \\
\text { established }\end{array}$ & Survey $(\mathrm{n}=500)$ & Hadi 2001 (44) \\
\hline $\begin{array}{l}\text { ARI=Acute } \\
\text { organizatic }\end{array}$ & ory infection; DSS=Demogra & surveillance system; NGO=Nor & sovernmental \\
\hline
\end{tabular}




\section{CONCLUSION}

In this paper, we sought to answer whether participation in group-lending reduces health inequities by addressing social exclusion. We applied a social exclusion framework to the available research on microcredit in Bangladesh. We described the exclusionary factors that microcredit attempts to combat, specifically poverty, the traditional norms that govern the conduct of women in public and urbanrural inequalities in wealth and development; we then suggest four pathways in which microcredit affects health. Ultimately, we argued that improving health is one of the most unambiguous benefits of microcredit in Bangladesh. However, microcredit is not an inclusive approach and for this reason is best accompanied with other complementary interventions.

Our analysis of microcredit, exclusion, and health is exploratory in nature. The analysis evaluates the impact of microcredit, a poverty-reduction strategy, on health outcomes, while health is not necessarily planned for in the design of the microcredit programme. None of the studies drawn on for this analysis were designed to inform a social exclusion analysis. More research into these relationships is required. Such research will be useful for the continued critique and modification of microcredit in designing new interventions for capability enhancement inclusive of social development and for greater health equity.

\section{ACKNOWLEDGEMENTS}

This work was funded by the World Health Organization (WHO) and undertaken as work for the Social Exclusion Knowledge Network established as part of the WHO Commission on the Social Determinants of Health. The views presented in this manuscript are those of the authors and do not necessarily represent the decisions, policy, or views of WHO or Commissioners.

The authors thank the following people for review of and feedback on earlier drafts of this paper: Lisa Basalla, Shelley Golden, Anne Martin Staple, Ruchira Naved, Syed Masud, Wendy Werner, and Jeffrey Motu.

\section{REFERENCES}

1. Hulme D, Moore K. Why has microfinance been a policy success in Bangladesh and beyond? Manchester: Global Policy Research Group, Economic and Social Research Council, University of Manchester, 2007. 28 p.
2. Kabeer N. Conflicts over credit: re-evaluating the empowerment potential of loans to women in rural Bangladesh. World Dev 2001;29:63-84.

3. Hashemi S. Linking microfinance and safety net programs to include the poorest: the case of IGVD in Bangladesh. Washington, DC: Consultative Group to Assist the Poor, World Bank, 2001. 12 p.

4. Dunford C. Building better lives: sustainable integration of microfinance and education in child survival, reproductive health, and HIV/AIDS. Davis: Prevention for the Poorest Entrepreneurs Microcredit Summit Campaign, 2001. 31 p.

5. Armendariz B, Morduch J. The economics of microfinance. Cambridge, Massachusetts: MIT Press, 2007. $346 \mathrm{p}$.

6. Littlefield E, Morduch J, Hashemi S. Is microfinance an effective strategy to reach the Millenium Development Goals? Washington, DC: Consultative Group to Assist the Poor, World Bank, 2003. 11 p. (Focus note no. 24).

7. Khandker S. Microfinance and poverty: evidence using panel data from Bangladesh World Bank Econ Rev 2005;19:263-8.

8. Davis P. Rethinking the welfare regime approach: the case of Bangladesh. Global Soc Policy 2001;1:79-107.

9. Kabeer N. Social exclusion and the MDGs: challenge of 'durable inequalities' in the Asian context. IDS Bull 2006;37(3):64-78.

10. Sen B, Hulme D. The state of the poorest 2004/2005: chronic poverty in Bangladesh-tales of ascent, descent, marginality and persistence-overview. Manchester: Chronic Poverty Research Centre, University of Manchester, 2004. 12 p.

11. Sen B. Drivers of escape and descent: changing household fortunes in rural Bangladesh. World Dev 2003;31:513-34.

12. Cummins S, Curtis S, Diez-Roux AV, Macintyre S. Understanding and representing 'place' in health research: a relational approach. Soc Sci Med 2007; 65:1825-38.

13. Schuler RS, Hashemi SM, Badal SH. Men's violence against women in rural Bangladesh: undermined or exacerbated by microcredit programmes? Dev Pract 1998;8(2):148-57.

14. Amin R, Chowdhury J, Ahmed AU. Poor women's participation in income generating projects and their fertility regulation in rural Bangladesh. World Dev 1994;22:555-64.

15. Morduch J, Haley B. Analysis of the effects of microfinance on poverty reduction. New York, NY: Wagner, 2001. 163 p. (Working paper series). 
16. Consultative Group to Assist the Poor. Key principles of microfinance 2004. (www.cgap.org/p/site/c/template.rc/1.9.2747, accessed on 3 July 2007).

17. Matin I. Targeted development programmes for the extreme poor: experiences from BRAC experiments Research and Evaluation Division. Manchester: Chronic Poverty Research Centre, University of Manchester, 2002. 25 p. (CPRC working paper no. 20).

18. Naved R. The effect of a financially sustainable microcredit program on the participation of poor women. Dhaka: International Centre for Diarrhoeal Disease Research, Bangladesh, 2007. 36 p.

19. Pitt, M, Khandker, S. The impact of group based credit programs on poor households in Bangladesh: Does the Gender of Participants Matter? J Pol Econ 1998;106:958-66.

20. Goetz AM, Sen Gupta R. Who takes the credit? Gender, power and control over loan use in rural credit programs in Bangladesh. World Dev 1996;24:45-63.

21. Steele F. The impact of an integrated microcredit program on women's empowerment and fertility behaviour in rural Bangladesh. New York, NY: Population Council, 1998. 40 p.

22. Todd H. Women at the centre: Grameen bank borrowers after one decade. Dhaka: University Press Limited, 2005. $256 \mathrm{p}$.

23. Tilly C. Social boundary mechanisms. Philosoph Soc Sci 2004;34:211-36.

24. Mahmud S. Actually how empowering is microcredit? Dev Change 2003;34:577-605.

25. Amin R. Grameen microcredit to Grameen Kalyan Health Program. Dhaka: Academic Press and Publishers Library, 2007. 146 p.

26. Rogers EM. Diffusion of innovations. 5th ed. New York, NY: Free Press, 1995. 519 p.

27. Hamoudi A, Sachs J. Economic consequences of health status: a review of the evidence. Cambridge: Center for International Development, Harvard University, 1999. 25 p. (CID working paper no. 30).

28. Nanda P. Women's participation in rural credit programmes in Bangladesh and their demand for formal health care: is there a positive impact? Health Econ 1999:8;415-28.

29. Kabeer N. Snakes, ladders and traps: changing lives and livelihoods in rural Bangladesh. Brighton: Institute of Development Studies, 2004. 53 p. (CPRC working paper no. 50).

30. Pitt M, Khandker S, Chowdhury OM, Millimet D. Credit programs for the poor and the health status of children in rural Bangladesh. Int Econ Rev 2003;44:87118.
31. van Doorslaer E, O'Donnell O, Rannan-Eliya RP, Somanathan A, Adhikari S, Garg S et al. Catastrophic payments for health care in Asia. Health Econ 2007; 16:1159-84.

32. Wilkinson RG. The culture of inequality. In: Kawachi IK, Wilkinson B, RG, editors. The society and population health reader: income inequality and health. New York, NY: New Press, 1999:492-8.

33. Szreter S, Woolcock M. Health by association: social capital, social theory and the political economy of public health. Int J Epidemiol 2004;33:650-67.

34. Portes A. Social capital: it's origins and applications in modern sociology. Ann Rev Sociol 1998;24:1-24.

35. Amin R, St Pierre M, Ahmd A, Haq, R. Integration of an essential services package (ESP) in child and reproductive health and family planning with a microcredit program for poor women: experience from a pilot project in rural Bangladesh. World Dev 2001;29:1161-2.

36. Levin A, Rahman MA, Quayyum Z, Routh S, Khuda B. The demand for child curative care in two rural thanas of Bangladesh: effect of Income and women's employment. Int J Health Plann Manage 2001;16:179-94.

37. Hadi A. Integrating prevention of acute respiratory infections with microcredit programmes: the experience of BRAC Bangladesh. Public Health 2002;116:238-44.

38. Bhuiya A, Chowdhury M. Beneficial effects of a women-focused development programme on child survival: evidence from rural Bangladesh. Soc Sci Med 2002;55:1553-60.

39. Schuler RS, Hashemi SM, Riley AP. Credit programs, patriarchy and men's violence against women in rural Bangladesh. Soc Sci Med 1996;43:1729-42.

40. Schuler SR, Hashemi SM. Credit programs, women's empowerment, and contraceptive use in rural Bangladesh. Stud Fam Plann 1994;25:65-76.

41. Amin R, Li Y, Ahmed AU. Women's credit programs and family planning in rural Bangladesh: evidence from a recent survey. Int Fam Plann Perspect 1996; 22:158-62.

42. Steele F, Amin S, Naved R. Savings/credit group formation and change in contraception. Demography 2001;38:267-82.

43. Meekers D, Schuler S, Hashemi S. Can credit programs for women affect reproductive behaviour?: the case of rural Bangladesh. Pennsylvania: Population Research Institute, Pennsylvania State University, 1992. $27 \mathrm{p}$.

44. Hadi A. Promoting health knowledge through microcredit programmes: experiences of BRAC in Bangladesh. Health Promot Int 2001;16:219-27. 